\title{
Correction to: Real-World Prescription Pattern and Healthcare Cost Among Patients with Ulcerative Colitis in Japan: A Retrospective Claims Data Analysis
}

\author{
Celine Miyazaki (D) - Takuya Sakashita - Wonjoo Jung · \\ Shingo Kato
}

Published online: March 18, 2021

(C) The Author(s) 2021

Correction to: Adv Ther

https://doi.org/10.1007/s12325-020-01615-4

In the Original Article, there is an error in the Results section of the Abstract, the correct sentence should be "Use of biologics increased over the study period (biologics + 5-ASA: 0.0\% in 2009 to $3.0 \%$ in 2018)."

The original article has been corrected.

The original article can be found online at https://doi. org/10.1007/s12325-020-01615-4.

C. Miyazaki $(\bowtie) \cdot$ W. Jung

Open Access. This article is licensed under a Creative Commons Attribution-NonCommercial 4.0 International License, which permits any non-commercial use, sharing, adaptation, distribution and reproduction in any medium or format, as long as you give appropriate credit to the original author(s) and the source, provide a link to the Creative Commons licence, and indicate if changes were made. The images or other third party material in this article are included in the article's Creative Commons licence, unless indicated otherwise in a credit line to the material. If material is not included in the article's Creative Commons licence and your intended use is not permitted by statutory regulation or exceeds the permitted use, you will need to obtain permission directly from the copyright holder. To view a copy of this licence, visit http://creativecommons.org/licenses/bync/4.0/.

Health Economics Department, Janssen

Pharmaceutical K.K., Tokyo, Japan

e-mail: celinemiyazaki@gmail.com;

CMiyazak@its.jnj.com

T. Sakashita

Medical Science Liaison Department, Medical

Affairs, Janssen Pharmaceutical K.K., Tokyo, Japan

S. Kato

Department of Gastroenterology and Hepatology,

Saitama Medical Center, Saitama Medical

University, Saitama, Japan 